\title{
Analisa Akurasi Geometri Penggunaan Metode Injection Moulding Berbasis Printer 3D Untuk Produksi Implan Pada Bedah Cranioplasty
}

\author{
Djoko Kuswanto ${ }^{1,2}$, Alva Edy Tontowi ${ }^{3}$, Taufik Hidayat ${ }^{1}$, Agus Windharto ${ }^{1}$, dan Arie Kurniawan ${ }^{1}$ \\ ${ }^{1}$ Departemen Desain Produk Industri, Fakultas Teknik Sipil dan Perencanaan, \\ Institut Teknologi Sepuluh Nopember (ITS) \\ ${ }^{2}$ Program Studi Bioteknologi, Sekolah Pascasarjana Universitas Gadjah Mada \\ ${ }^{3}$ Jurusan Teknik Mesin dan Industri, Fakultas Teknik, Universitas Gadjah Mada \\ e-mail: crewol@prodes.its.ac.id
}

\begin{abstract}
Abstrak. Perkembangan teknologi printer 3D untuk medis, memungkinkan aplikasi produksi implan pra-operasi dengan keunggulan akurasi geometri yang baik, mengurangi waktu operasi dan resiko kehilangan banyak darah. Teknologi printer 3D paling populer dan potensial untuk dikembangkan masal di Indonenesia adalah fused deposition modeling/FDM. Akan tetapi memiliki kekurangan: single material, jenis material terbatas dan temperatur yang tinggi sehingga tidak bisa dicampur dengan material/senyawa bioaktif yang sensitif terhadap panas.
\end{abstract}

Pengembangan metode injection moulding berbasis printer 3D telah dilakukan pada penelitian ini dengan melakukan modifikasi alat, material, tahapan dan sistim produksi implan pra-operasi yang mengacu pada teknologi printer 3D untuk cranioplasty yang sudah dilakukan di negara maju. Untuk memastikan modifikasi ini bisa menghasilkan implan pra-operasi dengan akurasi geometri yang diinginkan, dilakukan karakterisasi terhadap deviasi dimensi implan yang diproduksi yaitu deviasi volume, deviasi tebal, deviasi panjang linear dan deviasi sudut kelengkungan permukaan implan, pada dua metode berbeda yang diuji, yaitu metode cranial/intra operatif dan metode injection moulding dengan menggunakan material polymethylmethacrylate/ PMMA.

Hasil yang didapatkan adalah deviasi volume implan yaitu sebesar $1.87 \pm 1.27 \%$ (injection moulding) dibandingkan $11.39 \pm 3.71 \%$ (metode cranial), deviasi tebal sebesar $2.54 \pm 0.86 \%$ (injection moulding) dibandingkan $7.35 \pm 1.43 \%$ (metode cranial), deviasi panjang linear sebesar $2.61 \pm 0.47 \%$ (injection moulding) dibandingkan 5.76 $\pm 0.79 \%$ (metode cranial) dan deviasi sudut kelengkungan permukaan sebesar $0.98 \pm 0 \%$ (injection moulding) dibandingkan $15.45 \pm 3.94 \%$ (metode cranial). Dapat diambil kesimpulan bahwa metode injection moulding lebih baik daripada metode $\mathrm{cranial} /$ intra operatif.

Kata Kunci: cranial bone defects, cranioplasty, printer 3D, injection moulding, FDM, PMMA

Abstract. Manufacture of pre-surgery implant may shorten the surgery duration and blood loss risk which provide medical benefit for patient. Additive manufacturing technology (AMT) have been applied in manufacture of pre-implant for cranioplasty surgery. Application of AMT allows production of pre-surgery implant with good geometrical accuracy. The most popular and potential printer 3D technology for mass developed in medical, is fused deposition modeling/FDM, because capable of producing its porosity high with a pattern laydown and the mechanical force good. However, FDM technology have some drawbacks i.e. the use of single type material, limited types of materials, and operation at high temperatures. This research was conducted to develop pre-surgery implants based on additive manufacturing technology to reconstruct and redesign cranial bone defects in Indonesia.

This research produced 3D printer-based of injection moulding method by modifying tools, materials, steps, and pre-surgery implants production system based on the additive manufacturing for cranioplasty. Geomatrical accuracy of implant was measured in term of volume deviation, thickness deviation, linear length deviation and surface curve angle deviation of implants. The study comparing two different methods tested: cranial/intra-operative method and injection moulding method using PMMA material.

The result showed that implant manufactured by 3D printer based mould have a higher geometrical accuracy as compared to cranial method. Volume deviation on the produced implants is $1.87 \pm 1.27 \%$ (injection moulding) compared to $11.39 \pm 3.71 \%$ (cranial method), thickness deviation of $2.54 \pm 0.86 \%$ (injection moulding) compared to $7.35 \pm 1.43 \%$ (cranial method), linear length deviation of $2.61 \pm 0.47 \%$ (injection moulding) compared to $5.76 \pm 0.79 \%$ (cranial method), curve length deviation of $1.54 \pm 0.77 \%$ (injection moulding) compared to $6.34 \pm 0.99 \%$ (cranial method) and surface curve angle deviation of $0.98 \pm 0 \%$ (injection moulding) compared to $15.45 \pm 3.94 \%$ (cranial method). From the data, it can be concluded that the injection moulding method is better suited than the cranial/intra-operative method.

Keyword: cranial bone defects, cranioplasty, printer 3D, injection moulding, FDM, PMMA

\section{PENDAHULUAN}

\section{A. Latar Belakang}

Defek tulang kepala (cranial bone defects) dan defek tulang wajah (cranio facial defects) merupakan kasus medis dimana tidak adanya jaringan tulang pada bagian cranial dan facial [1]. Defek tersebut dapat terjadi akibat trauma, nekrosis jaringan, penyakit infeksi dan degeneratif, pertumbuhan tulang abnormal, atau tindakan 
medis yang disengaja seperti craniectomy dan bedah kecantikan [2], [3], [4]. Defek tersebut dapat menyebabkan berkurangnya fungsionalitas tulang kranial dan perubahan anatomi [4].

Rekonstruksi dan redesain/perbaikan pada defek tulang kepala disebut sebagai tindakan cranioplasty [5]. Rekonstruksi defek tersebut dilakukan untuk memberikan perlindungan pada organ otak, meringankan rasa sakit pada area defek, memberikan nilai estetis, serta mengurangi kecemasan pasien. Tindakan cranioplasty dapat dilakukan baik melalui rekonstruksi osteoplastik maupun restorasi menggunakan aloplastik. Material yang umum digunakan sebagai implan alloplastik berupa logam inert, polymethylmethacrylate (PMMA), polyethylene (PE), maupun karet silikon [6].

Masing-masing bahan dan metode manufaktur yang tersedia untuk rekonstruksi tulang kepala/tengkorak menunjukkan kinerja tertentu dalam hal akurasi, sifat mekanik, waktu dan biaya produksi. Pemilihan bahan dan metode untuk pembuatan implan, tergantung pada kebutuhan pasien, bentuk dan lokasi dari cacat tulang dalam kombinasi dengan infrastruktur dan anggaran yang tersedia [7].

PMMA merupakan salah satu bahan aloplastik paling populer digunakan untuk tindakan cranioplasty. Penggunaan PMMA secara medis telah dilakukan sejak Perang Dunia kedua pada tahun 1940-an [8], [9] dan masih digunakan hingga saat ini [10]. PMMA merupakan material polimer termoplastik transparan. Resin akrilik ini memiliki keuntungan dalam penggunaannya yaitu dapat dicetak intraoperatif atau prefabrikasi untuk menyesuaikan dimensi defek [8], [9].

Saat ini, metode fabrikasi objek menggunakan printer 3 dimensi (3D) telah dikembangkan. Metode ini dapat mengatasi kelemahan pada metode intra-operatif dengan tangan yaitu dengan prefabrikasi implan [10]. Metode prefabrikasi ini melibatkan integrasi desain berbasis computer aided design (CAD) dan computer aided manufacturing (CAM) sehingga mampu membuat implan dengan struktur yang kompleks. Dimensi implan dapat dibuat secara akurat berdasarkan dimensi defek berdasarkan konversi hasil pencitraan medis dari instrumen magnetic resonance imaging (MRI) dan computed tomography (CT) scan menjadi digital modeling [11], [12].

Salah satu teknologi printer 3D yang saat ini banyak digunakan untuk keperluan biomedis adalah printer 3D dengan sistem FDM karena mampu menghasilkan porositas yang tinggi dengan pola laydown dan kekuatan mekanik yang baik. Tipe biomaterial polimer yang bisa digunakan pada sistem ini jauh lebih banyak dibandingkan dengan sistem yang lain. Akan tetapi, fabrikasi implan dengan metode ini dilakukan pada temperatur tinggi sehingga implan yang difabrikasi tidak bisa dicampur dengan material maupun senyawa bioaktif yang sensitif terhadap panas [13].

Oleh karena itu, modifikasi terhadap metode fabrikasi printer 3D sistem FDM perlu dilakukan untuk memanfaatkan kelebihan dari metode tersebut. Modifikasi dilakukan dengan memanfaatkan printer 3D sistem FDM untuk fabrikasi cetakan implan tulang kepala dengan bentuk yang kompleks. Dengan cetakan tersebut, implan tulang kepala diujicoba dengan metode injection moulding menggunakan polymer PMMA.

Akurasi geometri dari modifikasi terhadap sistem produksi implan pra-operasi berbasis printer 3D ini dilakukan dengan melakukan karakterisasi terhadap dimensi implan yaitu berupa deviasi volume, deviasi tebal, deviasi panjang linear dan deviasi sudut kelengkungan permukaan implan.

\section{B. Latar Belakang}

Berdasarkan paparan dalam latar belakang, permasalahan yang muncul pada penelitian ini adalah:

1. Apakah dapat dilakukan modifikasi terhadap sistem produksi implan pra-operasi berbasis printer 3D?

2. Apakah modifikasi metode produksi yang dilakukan dapat menghasilkan implan dengan dimensi yang akurat?

\section{Batasan Masalah}

1. Fraktur tulang yang menjadi subyek penelitian adalah fraktur tengkorak cranial/penutup dan pelindung otak, yang terdiri dari 8 tulang yaitu tulang frontal, dua tulang parietal, dua tulang temporal, tulang occipital, tulang sphenoid, dan tulang ethmoid.

2. Jenis fraktur yang menjadi subyek utama adalah fraktur yang menyebabkan lubang pada tulang cranial.

3. Jenis teknologi printer 3D yang dipakai sebagai obyek penelitian adalah teknologi FDM.

\section{Tujuan}

1. Melakukan modifikasi terhadap sistem produksi implan pra-operasi berbasis printer 3D.

2. Melakukan karakterisasi terhadap dimensi implan yang diproduksi yaitu berupa deviasi volume, deviasi tebal, deviasi panjang linear dan deviasi sudut kelengkungan permukaan implan.

\section{METODE PENELITIAN}

\section{A. Identifikasi Variabel}

1. Variabel pengaruh/bebas/independen.

Metode pembuatan implan, yang terdiri metode pencetakan langsung di cranial/intra-operatif, metode printer 3D dengan FDM, dan metode injection moulding.

2. Variabel terpengaruh/dependen.

Volume implan, tebal implan, panjang linear dan sudut kelengkungan permukaan implan.

3. Variabel terkendali

Komposisi PMMA acrylic yaitu perbandingan campuran bubuk polimer PMMA dan monomer cair MMA (methylmetacrylate), sebesar 2,0:1,2 (w/v).

\section{B. Prosedur Kerja}

Pada Gambar 1 menjelaskan tentang kerangka pikir penelitian yang pelaksanaannya dibagi menjadi 4 tahap, yaitu tahap pembuatan model untuk kebutuhan penelitian 
(konversi DICOM ke STL, pembuatan model solid tengkorak, model solid implan dan model solid cetakan), tahap proses pencetakan printer $3 \mathrm{D}$, tahap pelaksanaan pengujian metode (metode cranial/intraoperatif, metode print 3D dan metode injection moulding) serta tahap analisa hasil (tahap melakukan pengukuran hasil implan dari 2 metode yang dibandingkan metode cranial/intraoperatif dan metode injection moulding serta pengukuran geometri CAD sebagai kontrol).

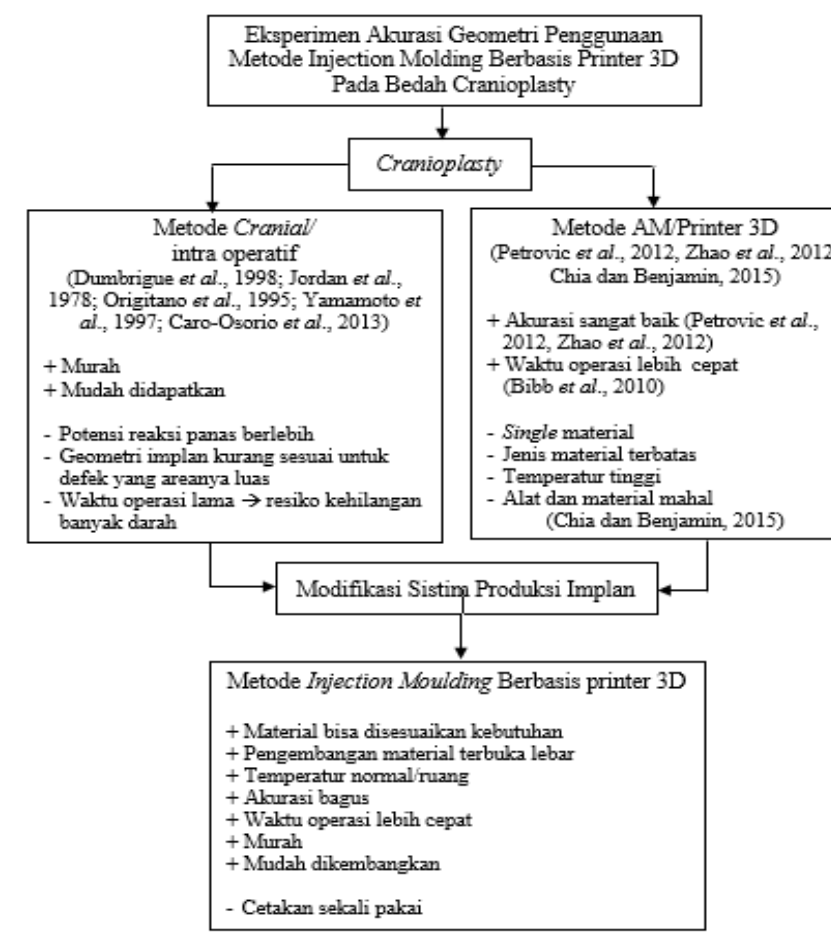

Gambar. 1. Skema kerangka pikir penelitian.

Subyek yang diteliti dalam penelitian ini adalah implan penutup cacat pada bedah cranioplasty berbahan PMMA bone cement menggunakan sistim produksi pra operasi dengan metode injection moulding berbasis printer 3D. Adapun variabel yang ditentukan dalam penelitian ini adalah variabel pengaruh/bebas/independen (metode pembuatan implan, yang terdiri metode pencetakan langsung di cranial, metode printer 3D dengan FDM, dan metode injection moulding), variabel terpengaruh/dependen (volume implan, tebal implan, panjang linear dan sudut kelengkungan permukaan implan), variabel terkendali (komposisi PMMA yaitu perbandingan campuran bubuk polimer PMMA dan monomer cair MMA, sebesar 2,0 : 1,2 w/v).

Jumlah sampel/replikasi pada penelitian eksperimen ini menggunakan rumus Federer (1991), yaitu: (t-1) (n-1) $\geq$ 15 , dimana $\mathrm{t}$ adalah banyaknya kelompok perlakuan, $\mathrm{n}$ adalah jumlah replikasi. Untuk $\mathrm{t}=4$ kelompok perlakuan, maka: (4-1) (n-1) $\geq 15$; $n \geq 15 / 3+1$; $n \geq 6$, jadi jumlah sampel minimal untuk masing-masing kelompok perlakuan adalah 6 sampel/replikasi.

Tabel 1. Kelompok perlakuan penelitian

\begin{tabular}{c|c|c|c|c}
\multicolumn{6}{c}{ Tabel 1. Kelompok perlakuan penelitian } \\
\hline \hline & 1 & 2 & 3 & 4 \\
\hline Bentuk/model cacat & $\mathrm{A}$ & $\mathrm{A}$ & $\mathrm{A}$ & $\mathrm{B}$ \\
\hline \hline
\end{tabular}

\begin{tabular}{l|c|c|c|c}
\hline \hline Metode & $\begin{array}{c}\text { Eksisting } \\
\text { (simulasi) }\end{array}$ & $\begin{array}{c}\text { Printer } \\
3 D\end{array}$ & $\begin{array}{c}\text { Printer } \\
3 D\end{array}$ & $\begin{array}{c}\text { Printer } \\
3 D\end{array}$ \\
\hline Material cetakan & - & - & PLA & PLA \\
\hline Material implan & PMMA & PLA & PMMA & PMMA \\
\hline \hline
\end{tabular}

\section{Metode Pengukuran}

1. Variabel volume: perbandingan volume hasil akhir implan kelompok perlakuan 1, 2 dan 3. Pengukuran volume dengan cara mengetahui berat implan dan density (massa jenis material). Data pengukuran digital menggunakan aplikasi AutoCad sebagai acuan kontrol.

2. Variabel geometri: perbandingan tebal (mm), panjang linear (mm), pada 6 titik [14] dan sudut kelengkungan $\left(^{\circ}\right)$ pada 4 lokasi, yang letaknya ditentukan antara implan dan defects yang ada pada kelompok perlakuan 1, 2 dan 3. Pengukuran dilakukan dengan digital caliper dan data pengukuran digital menggunakan aplikasi AutoCad sebagai acuan kontrol.

Tahapan yang dilakukan dalam penelitian ini, seperti bisa dilihat pada Gambar 2 adalah:

a. Konversi file DICOM ke STL

b. Pembuatan Model A (lihat Tabel 1)

c. Pembuatan Model B (lihat Tabel 1)

d. Percobaan Rekonstruksi dengan Metode Cetak Langsung pada Cranial/Intra operatif (Kelompok Perlakuan 1, lihat Tabel 1)

e. Proses Printer 3D dengan Cetak Langsung implan bentuk cacat A menggunakan printer 3D berbahan filamen PLA (Kelompok Perlakuan 2, lihat Tabel 1)

f. Proses Printer 3D dengan Cetak Moulding Implan Model A3 (Kelompok Perlakuan 3, lihat Tabel 1)

g. Tahapan Pengukuran

h. Analisa Hasil Pengukuran

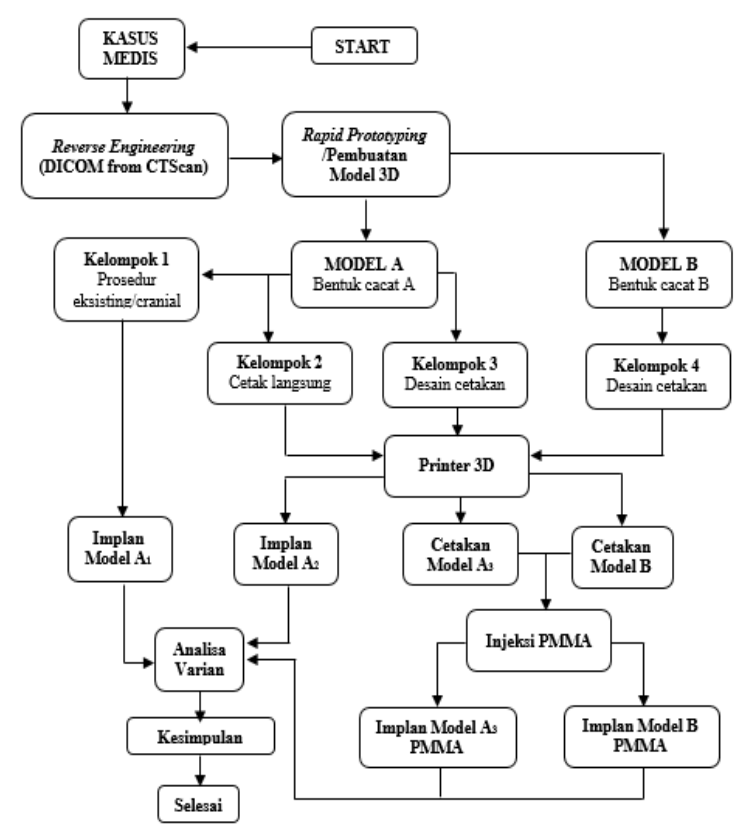

Gambar. 2. Alur prosedur kerja penelitian. 
Djoko Kuswanto, Alva Edy Tontowi, Taufik Hidayat, Agus Windharto, Arie Kurniawan Analisa Akurasi Geometri Penggunaan Metode Injection Moulding Berbasis Printer 3D Untuk Produksi Implan Pada Bedah Cranioplasty

\section{HASIL DAN PEMBAHASAN}

Pada penelitian ini, implan penutup defek telah diujicoba dengan 3 metode yaitu metode cetak langsung pada cranial/intra operatif (Gambar 3c), metode cetak langsung dengan print 3D (Gambar 3d) dan metode injection moulding; yaitu mencetak cetakan implan dengan print 3D (Gambar 3e). Untuk pengelompokan dan analisa ketelitian dimensi, mengacu pada metode yang menggunakan material sama yaitu PMMA, implan hasil sintesis dua dari tiga metode (cranial dan injection moulding) tersebut dibandingkan dengan dimesi gambar CAD berupa deviasi volume, deviasi tebal, deviasi panjang linear dan deviasi sudut kelengkungan permukaan.

Material yang digunakan untuk metode injection moulding pada penelitian ini adalah material yang sudah sering dan lama dipakai pada bedah cranioplasty di Indonesia, yaitu PMMA. PMMA biasa dikenal sebagai acrylic bone cement. Pada proses polimerisasi, PMMA berubah fase dari bentuk cair, menjadi semi pasta, lalu mengalami solidifikasi menjadi PMMA padatan. Pada metode injection moulding, PMMA dimasukkan ke dalam cetakan ketika berada dalam fase semi pasta.
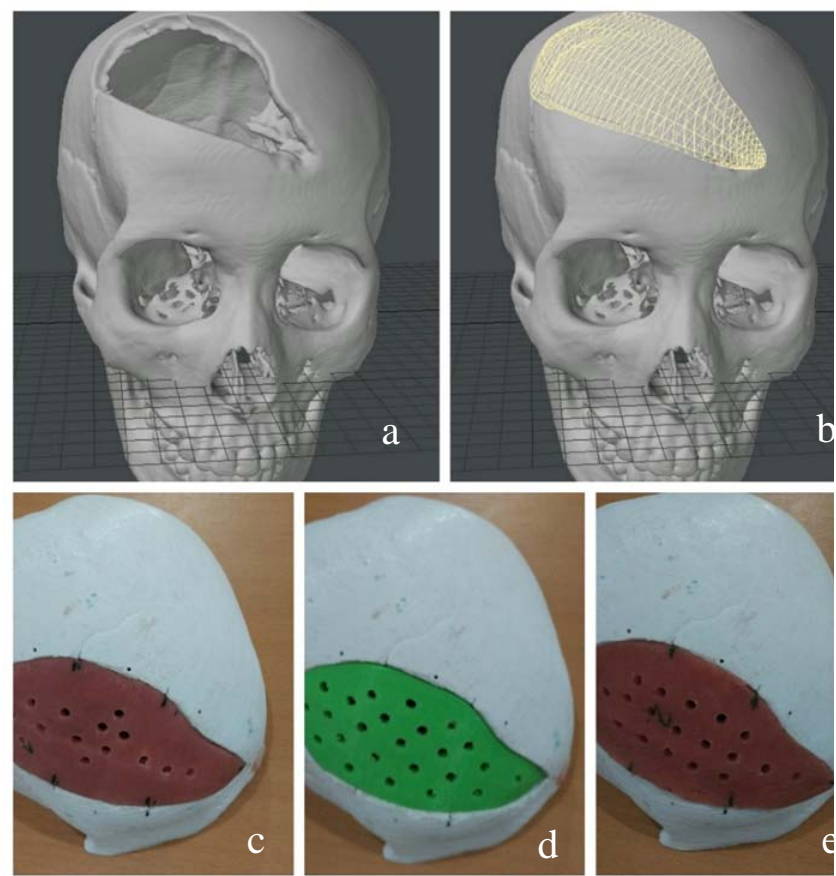

Gambar. 3. (a) 3D model hasil konversi dari CTScan, (b) Pembuatan 3D model implan pada aplikasi Lightwave3D, (c) Implan hasil metode intra-operatif, (d) Implan hasil metode printer 3D, (e) Implan hasil metode injection moulding.

\section{A. Hasil Pengukuran Volume Implan dan Deviasinya}

Tabel 2. Hasil pengukuran volume implan metode cranial (mm)

\begin{tabular}{cccccccc}
\hline \hline & $\begin{array}{c}\text { Kontr } \\
\text { ol }\end{array}$ & \multicolumn{6}{c}{ Cranial (density of PMMA $\left.1.18 \mathrm{~g} / \mathrm{cm}^{3}\right)$} \\
\hline $\begin{array}{c}\text { Sampe } \\
\mathrm{l}\end{array}$ & CAD & 1 & 2 & 3 & 4 & 5 & 6 \\
\hline Berat & 26.2 & 31.4 & 32.5 & 30.6 & 32.9 & 31.1 & 31.6 \\
\hline $\begin{array}{c}\text { Volum } \\
\mathrm{e}\end{array}$ & 32.75 & $\begin{array}{c}37.05 \\
2\end{array}$ & $\begin{array}{c}38.3 \\
5\end{array}$ & $\begin{array}{c}36.10 \\
8\end{array}$ & $\begin{array}{c}38.82 \\
2\end{array}$ & $\begin{array}{c}36.69 \\
8\end{array}$ & $\begin{array}{c}37.28 \\
8\end{array}$ \\
\hline \hline
\end{tabular}

Tabel 3. Hasil pengukuran volume implan metode injection moulding (mm)

\begin{tabular}{cccccccc}
\hline \hline & Kontrol & \multicolumn{6}{c}{ Injection Moulding (density of PMMA $\left.1.18 \mathrm{~g} / \mathrm{cm}^{3}\right)$} \\
\hline Sampel & CAD & 1 & 2 & 3 & 4 & 5 & 6 \\
\hline Berat & 26.2 & 28.5 & 28.8 & 28.6 & 28.8 & 28.7 & 28.8 \\
\hline Volume & 32.75 & 33.63 & 33.984 & 33.748 & 33.984 & 33.866 & 33.984 \\
\hline \hline
\end{tabular}

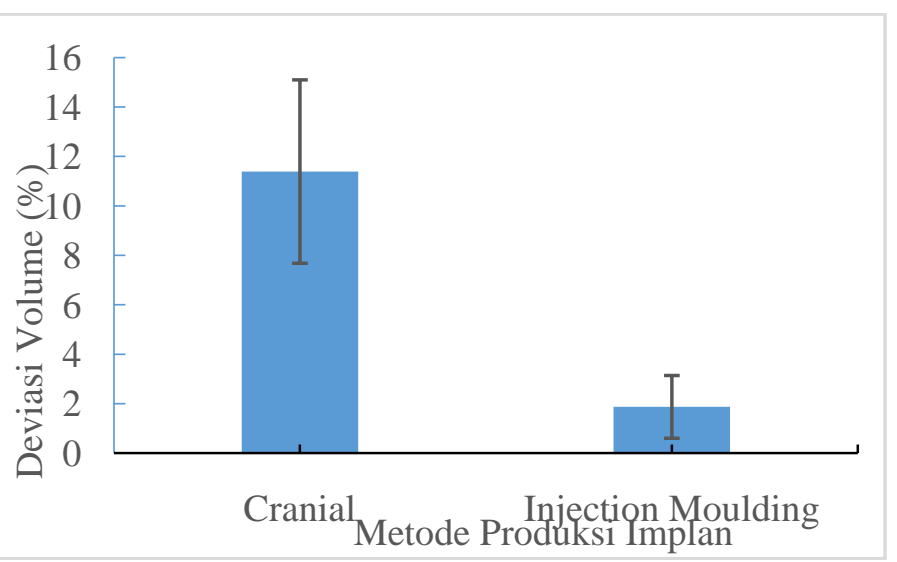

Gambar. 6. Deviasi volume implan pada metode cranial dan injection moulding.

Gambar 6, menunjukkan deviasi volume terbesar terjadi pada implan yang diproduksi dengan metode cranial yaitu sebesar $11.39 \pm 3.71 \%$. Deviasi volume terkecil terjadi pada implan yang diproduksi dengan metode injection moulding yaitu sebesar $1.87 \pm 1.27 \%$. Analisis statistik menunjukkan bahwa perlakuan metode memberikan pengaruh yang signifikan terhadap deviasi volume (anova satu arah, F2,17 = 23.166, p = 0.000). Uji post-hoc dengan Tukey menunjukkan bahwa deviasi volume dengan metode cranial lebih besar secara signifikan dibanding metode injection moulding.

\section{B. Hasil Pengukuran Tebal Implan dan Deviasinya}

Tabel 4. Hasil pengukuran tebal implan metode cranial (mm)

\begin{tabular}{cccccccc}
\hline \hline \multirow{2}{*}{ Titik Acuan } & CAD & \multicolumn{7}{c}{ Metode Cranial } \\
\hline A & 7.44 & 8.25 & 8.34 & 8.15 & 7.87 & 8.35 & 8.01 \\
\hline B & 7.68 & 8.17 & 8.21 & 8.05 & 8.26 & 8.1 & 8.32 \\
\hline C & 7.62 & 7.66 & 7.87 & 7.94 & 7.95 & 7.41 & 7.48 \\
\hline D & 8.72 & 7.57 & 8.07 & 7.44 & 7.41 & 7.73 & 7.14 \\
\hline E & 7.28 & 7.9 & 7.98 & 8.72 & 7.37 & 7.32 & 7.89 \\
\hline F & 7.09 & 7.34 & 7.45 & 7.47 & 7.21 & 7.29 & 7.36 \\
\hline \hline
\end{tabular}

Tabel 5. Hasil pengukuran tebal implan metode injection moulding

\begin{tabular}{cccccccc}
\hline \multicolumn{1}{c}{$(\mathrm{mm})$} \\
$\begin{array}{c}\text { Titik } \\
\text { Acuan }\end{array}$ & $\begin{array}{c}\text { CA } \\
\text { D }\end{array}$ & \multicolumn{7}{c}{ Metode Injection Moulding } \\
\hline A & 7.44 & 7.12 & 6.98 & 6.92 & $\begin{array}{c}6.9 \\
7\end{array}$ & 7.1 & $\begin{array}{c}7.0 \\
7\end{array}$ \\
\hline B & 7.68 & 7.23 & 7.17 & 7.34 & $\begin{array}{c}7.2 \\
8\end{array}$ & 7.32 & $\begin{array}{c}7.2 \\
8\end{array}$ \\
\hline C & 7.62 & 7.24 & 7.63 & 7.41 & $\begin{array}{c}7.4 \\
2\end{array}$ & 7.54 & $\begin{array}{c}7.4 \\
8\end{array}$ \\
\hline D & 8.72 & 8.59 & 8.57 & 8.67 & $\begin{array}{c}8.4 \\
8\end{array}$ & 8.61 & $\begin{array}{c}8.5 \\
9\end{array}$ \\
\hline E & 7.28 & 7.27 & 7.39 & 7.26 & $\begin{array}{c}7.2 \\
9\end{array}$ & 7.34 & 7.3 \\
\hline \hline
\end{tabular}




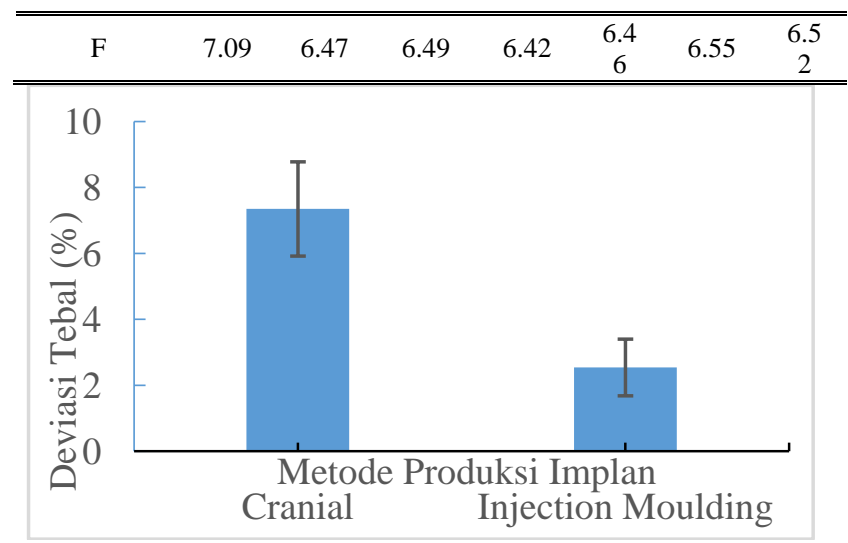

Gambar. 7. Deviasi tebal implan pada metode cranial dan injection moulding.

Bisa dilihat pada Gambar 7, deviasi tebal terbesar terjadi pada implan yang diproduksi dengan metode cranial yaitu sebesar $7.35 \pm 1.43 \%$. Deviasi tebal terkecil terjadi pada implan yang diproduksi dengan metode injection moulding yaitu sebesar $2.54 \pm 0.86 \%$. Analisis statistik menunjukkan bahwa perlakuan metode memberikan pengaruh yang signifikan terhadap deviasi tebal (anova satu arah, F2,17 = 51.924, p = 0.000). Uji post-hoc dengan Tukey menunjukkan bahwa deviasi tebal dengan metode cranial lebih besar secara signifikan dibanding metode injection moulding.

\section{Hasil Pengukuran Panjang Linear Implan dan Deviasinya}

Tabel 6. Hasil pengukuran panjang linear implan metode cranial (mm)

\begin{tabular}{cccccccc}
\hline \hline Titik Acuan & CAD & \multicolumn{6}{c}{ Metode Cranial } \\
\hline AB & 36.2 & 38.35 & 38.01 & 38.98 & 38.93 & 36.8 & 38.14 \\
\hline BC & 34.8 & 36.86 & 36.78 & 37.05 & 37.52 & 36.48 & 36.37 \\
\hline CD & 48.7 & 50.45 & 51.22 & 50.25 & 50.67 & 50.82 & 50.2 \\
\hline DE & 41 & 44.65 & 43.99 & 43.82 & 44.68 & 44.27 & 43.32 \\
\hline EF & 37.3 & 40.12 & 40.67 & 39.61 & 40.85 & 39.21 & 39.6 \\
\hline FA & 43.6 & 45.34 & 45.81 & 45.43 & 45.26 & 44.67 & 44.89 \\
\hline \hline
\end{tabular}

Tabel 7. Hasil pengukuran panjang linear metode injection moulding (mm)

\begin{tabular}{cccccccc}
\hline \hline Titik Acuan & CAD & \multicolumn{7}{c}{ Metode Injection Moulding } \\
\hline AB & 36.2 & 36.83 & 36.55 & 36.86 & 36.81 & 36.67 & 36.64 \\
\hline BC & 34.8 & 35.23 & 35.69 & 35.69 & 35.39 & 35.42 & 35.29 \\
\hline CD & 48.7 & 48.66 & 48.52 & 47.57 & 48.06 & 47.26 & 47.34 \\
\hline DE & 41 & 42.47 & 42.2 & 42.54 & 42.26 & 42.38 & 42.41 \\
\hline EF & 37.3 & 37.63 & 38.02 & 38.21 & 38.36 & 38.47 & 37.59 \\
\hline FA & 43.6 & 44.52 & 44.7 & 44.32 & 45.27 & 44.96 & 45.27 \\
\hline \hline
\end{tabular}

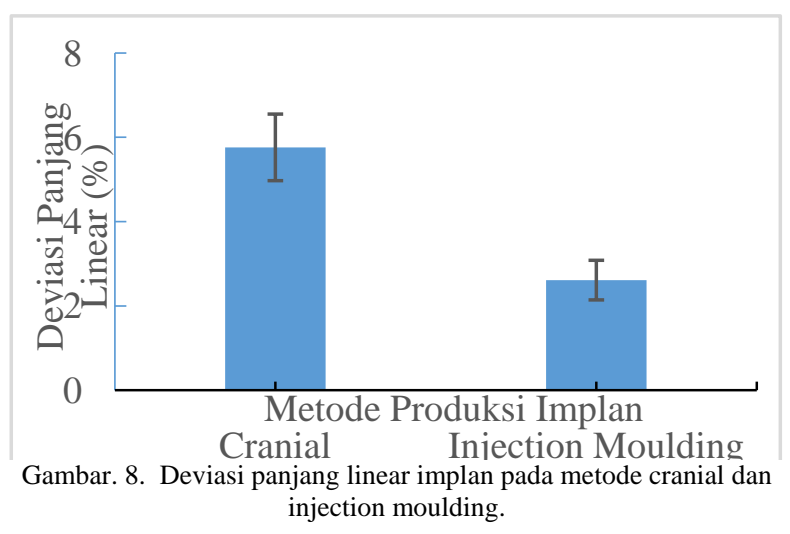

Pada Gambar 8, deviasi panjang linear terbesar terjadi pada implan yang diproduksi dengan metode cranial yaitu sebesar $5.76 \pm 0.79 \%$. Deviasi panjang linear terkecil terjadi pada implan yang diproduksi dengan metode injection moulding yaitu sebesar $2.61 \pm 0.47 \%$. Analisis statistik menunjukkan bahwa perlakuan metode memberikan pengaruh yang signifikan terhadap deviasi panjang linear (anova satu arah, F2,17 = 44.583, $\mathrm{p}=$ 0.000). Uji post-hoc dengan Tukey menunjukkan bahwa deviasi panjang linear dengan metode cranial lebih besar secara signifikan dibanding metode injection moulding.

\section{Hasil Pengukuran Sudut Kelengkungan Implan dan Deviasinya}

Tabel 8. Hasil pengukuran sudut kelengkungan metode cranial $\left(^{0}\right.$ )

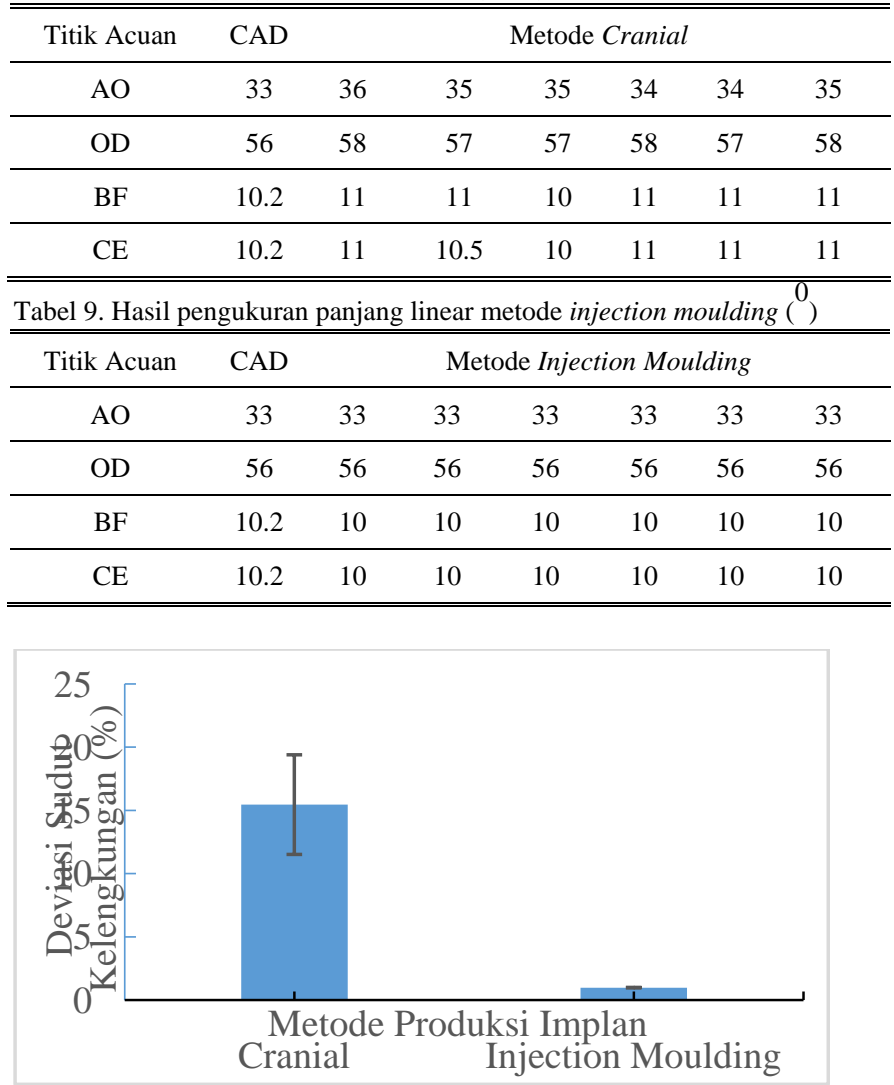

Gambar. 9. Deviasi sudut kelengkungan implan pada metode cranial dan injection moulding.

Deviasi sudut kelengkungan permukaan terbesar terjadi pada implan yang diproduksi dengan metode cranial yaitu sebesar $15.45 \pm 3.94$ \%. Deviasi sudut kelengkungan 
permukaan bernilai persis sama, terjadi pada implan yang diproduksi dengan metode print 3D dan injection moulding yaitu sebesar $0.98 \pm 0 \%$. Analisis statistik menunjukkan bahwa perlakuan metode memberikan pengaruh yang signifikan terhadap deviasi sudut kelengkungan permukaan (anova satu arah, F2,17 = 81.124, $\mathrm{p}=0.000)$. Uji post-hoc dengan Tukey menunjukkan bahwa deviasi sudut kelengkungan permukaan dengan metode cranial lebih besar secara signifikan dibanding metode injection moulding.

\section{E. Modifikasi Produksi Implan Pra Operasi}

Di Indonesia, metode produksi implan untuk cranioplasty masih menggunakan metode cranial/intraoperatif dengan bahan PMMA, sementara di negaranegara maju telah memanfaatkan printer 3D dengan bahan titanium atau polyetheretherketone (PEEK). Penerapan metode printer 3D untuk cranioplasty di Indonesia, selain terkendala hal-hal non teknis seperti harga alat dan material yang mahal, juga menyangkut kontinuitas ketersediaan alat dan material serta proteksi teknologi.

Untuk keperluan itu, beberapa modifikasi telah dilakukan, yang merupakan keaslian dari penelitian ini; mengacu pada tahapan proses produksi implan praoperasi yang sudah dilakukan di negara-negara maju dan sudah diterapkan pada banyak pasien, yaitu proses reverse engineering - rapid prototyping - printer 3D menurut rujukan [15], [16] dan [17], untuk pembuatan implan penutup defek pada bedah cranioplasty. Bisa dilihat di Tabel 10.

Tabel 10. Modifikasi Proses Manufaktur Printer 3D

\begin{tabular}{lcc}
\hline \hline Variabel & Rujukan [15], [16], [17] & Kuswanto. 2016 \\
\hline $\begin{array}{l}\text { Format Data } \\
\text { Input }\end{array}$ & CTScan/DICOM & CTScan/DICOM \\
\hline $\begin{array}{l}\text { Aplikasi Reverse } \\
\text { Engineering }\end{array}$ & Mimic 14.0 & Invesalius 3 Beta5 \\
\hline $\begin{array}{l}\text { Rapid } \\
\text { Prototyping }\end{array}$ & 3-Matic & Lightwave 2015 \\
\hline $\begin{array}{l}\text { Additive } \\
\text { Manufacturing }\end{array}$ & DMLS/SLA & FDM \\
\hline Material implan & Titanium/PEKK & PMMA \\
\hline Teknik Produksi & Direct/Positive object & Mold/Negative object \\
\hline \hline
\end{tabular}

\section{KESIMPULAN}

Berdasarkan penelitian ini, metode injection moulding berbasis printer 3D ini, dapat disimpulkan bahwa:

1. Modifikasi terhadap sistem produksi implan praoperasi berbasis printer 3D dapat dilakukan dengan metode injection moulding.

2. Metode injection moulding lebih baik daripada metode cranial/intra operatif dan tidak berbeda signifikan dengan metode print 3D berdasarkan hasil uji statistik anova satu arah terhadap deviasi dimensi implan berupa volume, tebal, panjang linear dan sudut kelengkungan permukaan implan.

Beberapa hal yang dapat disarankan dan perlu adanya penelitian lanjutan, antara lain:

a. Percobaan dengan jenis material yang lain. b. Pengembangan penggunaan metode injection moulding untuk kasus medis yang lain, seperti tulang mandibula, tulang maxilla, tulang orbital, tulang zygomatic, tulang lacrimal, dan lain-lain.

c. Percobaan hasil implan metode injection moulding pada uji sitotoksik in-vitro, in-vivo (sel), in-vivo (hewan uji) untuk kemungkinan penerapan nyata dalam dunia medis.

\section{DAFTAR PUSTAKA}

[1] Da Silva, A. L. F., Meireles, B. A., Rodrigues, S. N., Luis Miranda, P. F., Henrique, B. A., Michael, M. 2014. "Customized Polymethyl Methacrylate Implants for the Reconstruction of Craniofacial Osseous Defects." Edited by Fabio Roccia. Case Reports in Surgery (Hindawi Publishing Corporation) Article ID 358569. doi:10.1155/2014/358569.

[2] Gabrielli, R. M. F., Gabrielli, C. M. A., HochuliVieira E., PereiraFillho VA. 2004. "Immediate Reconstruction of Frontal Sinus Fractures: Review of 26 Cases." Journal of Oraland Maxillofacial Surgeryy, vol.62, no.5 582-586.

[3] Lee, S., Wu, C., Lee, S. T., Chen, P. 2009. "Cranioplasty Using Polymethyl Methacrylate Prostheses." Journal of Clinical Neuroscience 16 56-63.

[4] SzpalSki, C., Barr, J., Wetterau, M., Saadeh, P. B., Warren, S. M. 2010. "Cranial Bone Defects: Current and Future Strategies." Neurosurg Focus 29:1-11. Accessed September 12, 2015. doi:10.3171/2010.9. FOCUS10201.

[5] Fusetti, S., Hammer, B., Kellman, R., Matula, C., Strong, E B. 2011. Cranial Vault and Skull Base-Special Considerations: Cranioplasty. AO Foundation. Accessed Maret 24, 2013.

[6] Dumbrigue, H. B., Arcuri, M. R., La Velle, W. E., Ceynar, K. J. 1998. "Fabrication Procedure for Cranial Prostheses." Journal Prosthetic Dental 229-231.

[7] Cabraja, M., Klein, M., Lehmann, T. N. 2009. "Long-term Results Following Titanium Cranioplasty of Large Skull Defects." Journal of Neurosurgical Focus Vol. 26 No.6 E10.

[8] Elkins, C. W., Cameron, J. E. 1946. "Cranioplasty with Acrylic Plates." Neurosurgeon Vol. 3 199-205.

[9] Woolf, J. L., Walker, A. E. 1945. "Cranioplasty: collective review." Int Abs Surg. 81:1-23.

[10] Caro-Osorio, E., Garza-Ramos, R. D., Martinez-Sanchez, S. R., Olazaran-Salinas, F. 2013. "Cranioplasty With Polymethylmethacrylate Prostheses Fabricated by Hand Using Original Bone Flaps: Technical Note and Surgical Outcomes." Surgical Neurology International.

[11] Winder, J., Bibb, R. 2005. "Medical rapid prototyping technologies: state of the art and current limitations for application in oral and maxillofacial surgery." J Oral Maxillofac Surg. 63(7):1006-1015.

[12] Colin, A., Boire, J. Y. 1997. "A Novel Tool for Rapid Prototyping and Development of Simple 3D Medical Image Processing Applications on PCs. Comput Methods." Programs Biomed. 53:8792.

[13] Chia, H. N., Wu, B. M. 2015 9:4. "Recent Advances in 3D Printing of Biomaterials." Journal of Biological Engineering 1-14.

[14] Salmi, M., Paloheimoa, K. S., Tuomia, J., Wolff, J., Mäkitie, A. 2013. "Accuracy of Medical Models Made by Additive Manufacturing (Rapid Manufacturing)." Cranio-Maxillo-Facial Surgery 603-609.

[15] Van der Meer WJ, Bos RRM, Vissink A, Visser A. 2013. "Digital planning of cranial implants." British Journal of Oral and Maxillofacial Surgery 51 450-452.

[16] Bagaria, V., Rasalkar, D., Bagaria, S. K., Ilyas, J. 2011. "Medical Applications of Rapid Prototyping - A New Horizon." Advanced Applications of Rapid Prototyping Technology in Modern Engineering 1-21.

[17] Zhao, L., Patel, P. K., Mimis, C. 2012. "Application of Virtual Surgical Planning with Computer Assisted Design and Manufacturing Technology to Cranio-Maxillofacial Surgery." Archives of Plastic Surgery (The Korean Society of Plastic and Reconstructive $\quad$ Surgeons) 39: 309-316. doi:10.5999/aps.2012.39.4.309 